\title{
Annea muistaen - In memoriam Anne Haila
}

Mervi Ilmonen \& Sampo Ruoppila

Yhdyskuntasuunnittelu-lehti haluaa tällä numerolla kunnioittaa äskettäin yllättäen menehtynyttä lehden entistä päätoimittajaa ja toimituksen jäsentä, kaupunkitutkimuksen professori Anne Hailaa (1953-2019). Numero koostuu Annen kollegoiden ja oppilaiden lyhyistä puheenvuoroista, jotka koskevat kaupunkitutkimusta, Annen edustamaa tutkimusalaa.

Pyysimme kirjoittajia pohtimaan omasta näkökulmastaan kaupunkitutkimusta tutkimusalana, sen merkitystä tai yhteiskunnallisia kontribuutioita, tai kaupunkitutkimuksen nykyisiä ja tulevaisuuden tärkeimpiä kysymyksiä. Maininnat Anneen jätimme kirjoittajien harkinnan varaan.

Pienartikkelit jakautuvat karkeasti kolmeen aihepiiriin. Osa käsittelee kaupunkitutkimuksen kenttää kokonaisuutena, esimerkiksi tutkimusalan kehityskaarta, vaikutuksia, uusiutumista ja tulevia haasteita. Toinen kokonaisuus muodostuu kirjoituksista, jotka käsittelevät jotain kaupungistumiseen tai kaupunkikehityksen dynamiikkaan liittyvää ilmiötä. Kolmas ryhmä pienartikkeleita liittyy maankorkoteoriaan, jota Anne kehitti.

Anne oli kiistatta Suomen kansainvälisesti tunnetuin kaupunkitutkija, ehkä paremmin tunnettu kansainvälisessä tutkijayhteisössä kuin kotimaassaan. Hänellä oli useita luottamustehtäviä erityisesti kansainvälisen sosiologian seuran (International Sociological Association, ISA) kaupunki- ja aluetutkimuksen ryhmässä (RC 21, Urban and Regional Development), joka koostuu 
maailmanlaajuisesti merkittävistä kaupunkitutkimuksen teorian kehittäjistä. Hyvien kansainvälisten suhteidensa ansiosta Anne saattoi tarjota ohjaamilleen opiskelijoille ja muille häneen tukeutuneille tutkijoille vierailumahdollisuuksia ja yhteyksiä eri maiden yliopistoihin. Anne myös loi monitieteisen kaupunkitutkimusyhteisön Helsingin yliopiston yhteiskuntapolitiikan laitokselle, rekrytoimalla sinne eri oppialoja edustaneita, lupaavia tai jo kannuksensa keränneitä tutkijoita.

Teemanumero koottiin erittäin nopealla aikataululla. Kiitämme lämpimästi kaikkia kirjoittajia työpanoksesta ja ripeydestä.

The Finnish Journal of Urban Studies wishes to pay tribute to its former Editor-in-Chief and member of the Editorial Board, Professor of Urban Studies Anne Haila, who unexpectedly passed away this September. The special issue consists of short papers by invited authors, both Finnish and international, representing Anne's colleagues and students.

The authors were requested to reflect on urban studies as a research field, its importance or societal contributions, or contemporary or future topics. Whether the texts include memories of Anne or references to her work was up to the authors.

The papers are roughly divided into three categories. The first set elaborates on urban studies as a field, including its development, impact, renewal and new challenges. The second set of writings is about various urban phenomena or development dynamics. The third set is connected to Anne's work on urban land rent theory.

Anne was undoubtedly the most globally well-known urban scholar in Finland. She was active in several international research organizations and groups, especially in the International Sociological Association and its Research Committee 21, Urban and Regional Development. Through her international relationships, she was able to offer her students and colleagues useful contacts with universities in different countries. Anne also created a multidisciplinary urban research community in the University of Helsinki's Department of Social and Public Policy, recruiting promising or meritorious researchers from various fields.

This special issue was compiled in a short period of time. We are most grateful to the authors for their timely contributions. 